Research Article

\title{
Morphometric Study of Human Occipital Condyles in Reference to Condylar Resection during Transcondylar Approach
}

\author{
Sachin Patil', Dharmendra Kumar ${ }^{2}$ \\ ${ }^{1}$ Assistant Professor, Department of Anatomy, ANIIMS, Port Blair, A\&N Islands. \\ ${ }^{2}$ Associate Professor \& Head, Department of Physical Medicine and Rehabilitation, ANIIMS, Port Blair, A\&N Islands. \\ DOI: https://doi.org/10.24321/2454.8642.201907
}

\section{I $\quad \mathbf{N} \quad \mathbf{F} \quad \mathbf{O}$}

\begin{abstract}
Corresponding Author:
Dharmendra Kumar, Department of Physical Medicine and Rehabilitation, ANIIMS, Port

Blair, A\&N Islands.

E-mail Id:

dharmendra744101@gmail.com

Orcid Id:

https://orcid.org/0000-0001-9722-5107

How to cite this article:

Patil S, Kumar D. Morphometric Study of Human Occipital Condyles in Reference to Condylar Resection during Transcondylar Approach. Rec Adv Path Lab Med 2019; 5(2): 11-13.
\end{abstract}

Date of Submission: 2019-07-15

Date of Acceptance: 2019-08-01

\section{$\begin{array}{llllllll}\mathbf{A} & \mathbf{B} & \mathbf{S} & \mathbf{T} & \mathbf{R} & \mathbf{A} & \mathbf{C} & \mathbf{T}\end{array}$}

Introduction: Knowledge of the anatomy of occipital condyles is very useful for the surgeon during condylar drilling to avoid injury to neural structures.

Material and Methods: This study was conducted on occipital condyles in 100 dried human skulls of unknown age and sex. The morphometric analysis was performed for the length, width, height, anterior intercondylar distance and posterior intercondylar distance of occipital condyles on both sides.

Results: The mean values were found to be $24.6 \mathrm{~mm}$ (right) and 22.65 $\mathrm{mm}$ (left) for the length, $12.48 \mathrm{~mm}$ (right) and $13.32 \mathrm{~mm}$ (left) for the width and $9.37 \mathrm{~mm}$ (right) and $9.49 \mathrm{~mm}$ (left) for the height. The mean anterior and posterior intercondylar distances were found to be 21.48 $\mathrm{mm}$ and $42.3 \mathrm{~mm}$ respectively.

Conclusion: The knowledge of morphometric parameters can be used for the planning of the extent of condylar resection during transcondylar approach without damaging the neurological structures.

Keywords: Foramen Magnum, Morphometry, Occipital Condyles

\section{Introduction}

The articular surfaces of the occipital condyles are convex antero-posteriorly and from side to side which form an important joint of the neck; the atlanto-occipital joint. The margins of condyles give attachment to the capsules of the atlanto-occipital joints and the medial side provides attachment to the alar ligament. ${ }^{1}$ The knowledge of the anatomy of occipital condyles is very useful for the surgeon during condylar drilling to avoid injury to the neural structures. For transcondylar extension during lateral approach, the condylar drilling is done on the basis of the length of the occipital condyle along its long axis and width of the condyle. This knowledge helps safe resection of the posterior $1 / 3^{\text {rd }}$ of the occipital condyle. ${ }^{2}$ The other important factors are overriding of the occipital condyle in the foramen magnum and the relationship of condyles to the hypoglossal canal. ${ }^{3}$ The study was conducted to document some important morphometric measurements useful for the far lateral transcondylar approach. This knowledge is useful for not only for surgeons but also for anatomists, forensic and anthropological experts. ${ }^{4}$ 


\section{Material and Methods}

This study was conducted on occipital condyles in 100 dried human skulls of unknown age and sex collected from the bone bank of medical college. The morphometric analysis was performed for the length, width and height of occipital condyles on both sides. The height was measured at the center of the condyle. The other parameters examined were anterior intercondylar distance and posterior intercondylar distance (Figure 1). All parameters were measured with the help of digital Vernier caliper. Deformed and damaged skulls with any pathology were excluded from the study. All the data was tabulated and the difference between the measurements for the right side and left side was analysed statistically using the test.

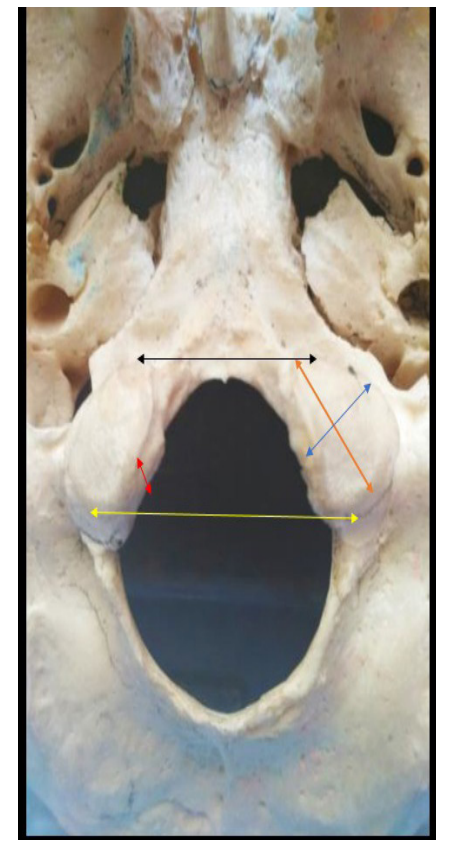

Figure I.Showing measurements of length (orange line), width (blue line) and height (red line) of occipital condyles, anterior intercondylar distance (black line) and posterior intercondylar distance (yellow line)

Table I.Showing the different parameters of occipital condyles

\begin{tabular}{|c|c|c|c|c|c|}
\hline Parameter & Side & Mean & SD & Range & t-test \\
\hline $\begin{array}{c}\text { Length of } \\
\text { occipital } \\
\text { condyle }\end{array}$ & Right & $\begin{array}{c}24.6 \\
\mathrm{~mm}\end{array}$ & 2.34 & $17-30$ & \multirow{2}{*}{0.45} \\
\cline { 2 - 5 } & Left & $\begin{array}{c}22.65 \\
\mathrm{~mm}\end{array}$ & 2.62 & $16-29$ & \\
\hline \multirow{2}{*}{$\begin{array}{c}\text { Width of } \\
\text { occipital } \\
\text { condyle }\end{array}$} & Right & $\begin{array}{c}12.48 \\
\mathrm{~mm}\end{array}$ & 1.71 & $8-17$ & \multirow{2}{*}{0.12} \\
\cline { 2 - 5 } & Left & $\begin{array}{c}13.32 \\
\mathrm{~mm}\end{array}$ & 1.63 & $10-16$ & \\
\hline
\end{tabular}


preoperatively by using radiological techniques like CT scans.

\section{Conflict of Interest: None}

\section{References}

1. Kalthur SG, Padmashali S, Gupta C et al. Anatomic Study of the Occipital Condyle and its Surgical Implications in Transcondylar Approach. J Craniovertebral Junction Spine 2014; 5(2): 71-77.

2. Barut N, Kale A, Turan Suslu H et al. Evaluation of the Bony Landmarks in Transcondylar Approach. Br J Neurosurg 2009; 23: 276-281.

3. Muthukumar N, Swaminathan R, Venkatesh $\mathrm{G}$ et al. A Morphometric Analysis of the Foramen Magnum Region as it Relates to the Transcondylar Approach. Acta Neurochir 2005; 147: 889-895.

4. Ozer MA, CelikS, Govsa Fet al. Anatomical Determination of a Safe Entry Point for Occipital Condyle Screw Using Three-dimensional Landmarks. Eur Spine J 2011; 20: 1510-1517.

5. Verma R, Kumar S, Rai AM et al. The Anatomical Perspective of Human Occipital Condyle in Relation to the Hypoglossal Canal, Condylar Canal and Jugular Foramen and its Surgical Significance. Journal of Craniovertebral Junction \& Spine 2016; 7(4): 243-249.

6. Kumar S, Verma R, Rai AM et al. Morphological and Morphometric Analysis of Hypoglossal Canal in North Indian Dry Skulls and It's Significance in Cranial Base Surgeries. Journal of Clinical and Diagnostic Research: JCDR 2017; 11(3): 8-12.

7. Kumar A, Nagar M. Human Adult Occipital Condyles: A Morphometric Analysis. RRJMHS 2014; 3(4): 112-116.

8. Bayat $\mathrm{P}$, Bagheri $\mathrm{M}$, Ghanbari $\mathrm{A}$ et al. Characterization of Occipital Condyle and Comparison of its Dimensions with Head and Foramen Magnum Circumferences in Dry Skulls of Iran. Int J Morphol 2014; 444-448.

9. Kavitha S, Chandrasekaran S, Anand A et al. Morphometric Study of Occipital Condyles in Adult Human Skulls. Int J Cur Res Rev 2013; 05(15): 18021805.

10. Tale AK, Kulkarni PR, Shaikh SI et al. Fupare. Morphometric Study of the Occipital Condyle and its Surgical Importance. Int J Anat Res 2016; 4(1): 1802-1805.

11. Bozbuga M, Ozturk A, Bayraktar B et al. Surgical Anatomy and Morphometric Analysis of the Occipital Condyles and Foramen Magnum. Okajimas Folia Anat Jpn 1999; 75: 329-334.

12. Avic E, Dagtekin A, Ozturk AH et al. Anatomical Variations of the Foramen Magnum, Occipital Condyle and Jugular Tubercle. Turk Neurosurg 2011; 21(2): 181-190.

13. Al-Mefty O, Borba LA, Aoki $\mathrm{N}$ et al. The Transcondylar Approach to Extradural Nonneoplastic Lesions of the
Craniovertebral Junction. J Neurosurg 1996; 84: 1-6. 14. Wen HT, Rhoton AL Jr, Katsuta T et al. Microsurgical Anatomy of the Transcondylar, Supracondylar and Paracondylar Extensions of the Far-lateral Approach. J Neurosur 1997; 87: 555-585. 